DOI https://doi.org/10.30525/978-9934-26-039-1-79

\title{
ВІДТВОРЕННЯ ПОЛІТИЧНИХ \\ ТА СОЦІОКУЛЬТУРНИХ РЕАЛІЙ У РОМАНІ М. ЛЕВИЦЬКОЇ «КОРОТКА ІСТОРІЯ ТРАКТОРІВ ПО-УКРАЇНСЬКИ»
}

\author{
Чумак Г. В. \\ кандидат філологічних наук, дочент, \\ доиент кафедри перекладу \\ Тернопільського національного педагогічного університету \\ імені Володимира Гнатюка \\ Деркач Г. С. \\ кандидат філологічних наук, \\ викладач кафедри іноземних мов \\ Тернопільського національного педагогічного університету \\ імені Володимира Гнатюка \\ м. Тернопіль, Україна
}

Одним із найбагатших засобів вираження національної своєрідності $\epsilon$ реалії, їхня семантична структура вміщає особливу інформацію культурну, унікальну з точки зору етнічного колориту.

У перекладознавчих працях лексема реалія як термін з'явилася у 40-х роках XX ст. Його вперше вжив А. Федоров щоб позначити не лексему, а національно-специфічний об'єкт. В українському перекладознавстві термін реалія вперше вжив О. Кундзіч, підкреслюючи при цьому неперекладність реалій: «Я схильний вважати народні пісні аналогічними реаліями даного народу, що, як правило, не перекладаються» [4, с. 152]. В. Коптілов називає реаліями «слова, щуо позначають предмети та явища, невідомі мові перекладу» [2, с. 45]. 3 цього твердження випливає той факт, що слова можуть бути реаліями в одній мові, але не бути такими в іншій. Український перекладознавець I. Корунець взагалі уникає терміна «realia», вживаючи замість нього дескриптивну полісемантичну фразу «the unit of specific national lexicon» $[3$, c. 62$]$.

Адекватне відтворення реалій, як слів специфічних для певного народу або країни, вимагає від перекладача особливої уваги. Аби передати суть реалії або, якщо це можливо, то і їі колорит, при перекладі застосовують різні стратегії. У випадку реалій доречно говорити не про переклад у буквальному розумінні, а лише про винайдення семантикостилістичного відповідника, або про трансляційне перейменування реалії. 
Існують такі способи трансляційного перейменування реалії за класифікацією Р.П. Зорівчак: транскрипція (транслітерація); гіперонімічне перейменування; дескриптивна перифраза; комбінована реномінація; міжована транспозиція на конототивному рівні; метод уподібнення; віднайдення ситуативного відповідника (контекстуальний переклад); калькування; інтерпретація реалії [1, с. 26-27].

В контексті функціонування української мови в англомовному чи білінгвальному українсько-англійському дискурсі особливо показовим, на нашу думку, є роман Марини Левицької «Коротка історія тракторів по-українськи». Марина Левицька, письменниця та етнічна українка 3 Шеффілда, педагог і авторка шести романів. «Коротка історія тракторів по-українськи» здобула премію Вудхауз, отримала британську національну літературну премію «Ноббіз». Перекладена 33 мовами, українською - у 2013 році.

Роман Марини Левицької максимально насичений українськими реаліями, тому і став об'єктом нашого аналізу. Деякі українські реалії авторка транслітерує і подає англійський еквівалент за допомогою гіперонімічного переіменування: khutor (settlement), чи дискриптивної перифрази: halushki (a paste with raw egg and semolina, bitten together), holubchik(little pigeon), kulak (wealthy farmer), Gulag (Stalin labor camps), a інші просто транслітеруються: Lada, kotletki, tak-tak, prestijeskiy auto, cossaks, kolkhoz, Trotskyst, blini.

У романі Марини Левицької знаходимо багаторазові згадки про війну, яка вплинула безпосередньо на сім'ю Маєвських-Очеретків.

The guard started to flick his whip around their legs. His face and ears had gone bright red. "You Ukrainians are ungrateful swine. We save you from the communists. We bring you to our country, we feed you, we give you work. And all you can think of it to thieve from us. Well, you have to be taught a lesson, don't you? We have a correction block for vermin like you. You have heard about F Block? You have heard how nicely we look after you there? Soon you will know».

Everyone had heard rumours about the Correction Block, row of fortyeight cramped windowless concrete cells half buried underground, like upright coffins, which stood on its own at one side of the Labour Re-educational Camp. In winter, cold and rain added to the torment; in summer, dehydration. Some had seen people dragged out crazed and skeletal after tenor twenty or thirty days. Longer than that, it was said, no one was dragged out alive [6, p. 125-126].

Реалії війни та поневірянь українців підсилюються такими політичними реаліями, як communists, Labour Re-educational Camp, які 
мають очевидну негативну конотацію. Українці, як нація, добре розуміють війну і ії наслідки, тому що колись це було реальністю і це трапилося з їхніми рідними. Українські чоловіки воювали на фронті, захищаючи свою землю, українські матері ховали своїх дітей, переживали страшні тортури - все це змінило їхнє і наше життя.

Українська історія багата на невідворотні трагедії. Голодомор був однією з них. Ця політична та соціальна реалія неодноразово згадується в тексті:

In the autumn of 1932 the army seized the entire harvest. Even the seed corn for the next year's planting was taken... The peasants ate their cows, chickens and goats; then their cats and dogs; then rats and mice; then there was nothing left to eat but grass. Between seven and ten million people died across Ukraine during the man-made famine [6, p. 67].

Реалія голодомор (штучно створений голод) передається за допомогою транспозиції на конотативному рівні man-made famine. Інша політична та соціальна реалія Гулаг або транскрибується Gulag, або передається за допомогою дескриптивної перифрази Stalin labor camps.

В наступному прикладі ця реалія є імпліцитною і передається за допомогою комбінованої реномінації та дескриптивної перифрази camps in Siberia for corrective re-education through labour і підсилюється ще однією політичною реалією чистки, яка передається за допомогою ситуативного відповідника purges. Політична реалія вороги народу передається методом калькування enemies of the people. Усі наведені приклади політичних та соціальних реалій мають експліцитно негативну конотацію і передають соціально-політичний контекст життя в Україні у 30-х роках.

Sonia ... had been lucky to escape in 1930, when her husband was taken away and shot. But those were just the first ripples of the purges. By 1937, the waves of arrests were mounting. Now shooting was too good for the enemies of the people - they were to be sent away to camps in Siberia for corrective reeducation through labour.

... But Sonia the survivor never recovered from her six days of interrogation. ... Her spirit was broken [6, p. 184].

В наступному прикладі маємо функціонування німецької реалії Ostarbeiter і ії калькований переклад англійською workers from the East.

... the Germans had taken over the village, put all the able-bodied young adults on to trains, and transported them to Germany to work in munitions factories. Ostarbeiter, they were called: workers from the East [6, p. 237].

Квінтесенцією жахливих нелюдських реалій воєнного часу $\epsilon$ наступний уривок: 
The labour camp at Drachensee was a huge, ugly, chaotic and cruel place. Forced labourers from Poland, Ukraine, Belarus, conscripted to boost the German was effort, communists and trade unions sent from the Low Countries for re-education, Gypsies, homosexual, criminals, Jews in transit to their deaths, inmates of lunatic asylums and captured resistance fighters, all lived cheek by jowl in low concrete lice-infested barracks. In such place, the only order was terror. And the rule of terror was reinforced at every level; each community had it's own hieharchy of terror [6, p. 268].

Українські соціально-політичні реалії 90-х теж додають національного колориту та пояснюють причини економічної еміграції.

But Ukraine must find her own way. At present, alas, we accept unquestioningly everything from the West. Some of course is good, some is rubbish... Russians, Germans, Americans - all of them-when they look at Ukraina, what do they see? Nothing but a source of cheap labour [6, p. 279-280].

В українському суспільстві жінка завжди сприймається як берегиня дому, на якій тримається вся сім'я. Мати, яка смачно готує, робить запаси, аби лише врятувати свою сім'ю від можливого голоду, пережитого, колись давно:

My mother had a pantry under the stairs stocked from floor to ceiling with tins of fish, meat, tomatoes, fruit, vegetables and puddings, packets with sugar... On the floor, in bottles and demi-jars, were gallons of a thick, mauve liquor made from plums, brown sugar and cloves... My mother had known ideology, and she had known hunger. When she was twenty-one, Stalin had discovered he could use the famine as a political weapon against the Ukrainian kulaks. She knew - and this knowledge never left her throughout her fifty years of live in England, and then seeped from her into the hearts of her children-she knew for certain that behind the piled-high shelves and abundantly stocked counters of Tesco... [6, p. 18-19]

В кожній культурі та в будь-якому суспільстві можна знайти реалії, які будуть невідомими для інших. Та коли ми починаємо розуміти реалії тієї чи іншої країни, ми починаємо розуміти саму країну та ії народ.

\section{Література:}

1. Зорівчак Р.П. Реалія і переклад (з матеріалів англомовних перекладів укр. прози). Львів, 1989. 108 с.

2. Коптілов В. В. Теорія і практика перекладу: н. посіб. К.: Юніверс, 2003. $280 \mathrm{c}$.

3. Корунець I.В. Теорія і практика перекладу: Підручник. Вінниця: Нова Книга, 2003. 342 с. 
4. Кундзіч О. Л. Творчі проблеми перекладу. К.: Дніпро, 1954. 264 с.

5. Чумак Г.В. Функціонування українських реалій в англомовному постмодерному тексті роману М. Левицької «Коротка історія тракторів по-українськи». Наукові записки Тернопільського національного педагогічного університет імені Володимира Гнатюка. Серія: Літературознавство /за ред. проф. М.Ткачука. Тернопіль: ТНПУ, 2009. Вип. 26. С. 302-312.

6. Lewycka M. A Short History of Tractors in Ukrainian. London, 2006. $326 \mathrm{p}$.

DOI https://doi.org/10.30525/978-9934-26-039-1-80

\title{
ЗАСОБИ ПЕРЕКЛАДУ НЕОЛОГІЗМІВ СУЧАСНОЇ АНГЛІЙСЬКОЇ МОВИ У СФЕРІ ІНФОРМАЦІЙНИХ ТЕХНОЛОГІЙ
}

\author{
Шевчук Т. Р. \\ асистент кафедри іноземних мов \\ природничо-математичних спеціальностей \\ Волинського національного університету імені Лесі Украӥнки \\ Ясінська О. В. \\ кандидат філологічних наук, \\ доиент кафедри іноземних мов \\ природничо-математичних спеціальностей \\ Волинського національного університету імені Лесі Украӥнки \\ м. Луиькк, Україна
}

Нові технології не стоять на місці, активно продовжуючи нарощувати свою експансію. Прогресуючі процеси комп'ютеризації роблять необхідним адекватний переклад відповідних текстів з однієї мови на іншу. Складність перекладу комп’ютерної лексики полягає у тому, що більшість термінів інформаційних технологій належить до безеквівалентної лексики, але це не означає неможливість їх перекладу. В даній науковій праці нами розглядаються особливості способів перекладу неологізмів та можливі варіанти передачі неологізмів сфери інформаційних технологій з англійської мови засобами української мови.

Технічний переклад є особливим видом перекладацької діяльності, основу якої складають творчі та розумові здібності перекладача. Значна 92 